\title{
SPARC wt Allele
}

National Cancer Institute

\section{Source}

National Cancer Institute. SPARC wt Allele. NCI Thesaurus. Code C92667.

Human SPARC wild-type allele is located within 5q31.3-q32 and is approximately $26 \mathrm{~kb}$ in length. This allele, which encodes SPARC protein, plays a role in cell morphology, cell cycle progression, calcium binding and deposition and extracellular matrix synthesis. 